\title{
Ibn Fadlan's Role in The Islamisation of Bulghar Society
}

\author{
Harliana Halim ${ }^{1 *}$, Kamaruzaman Yusoff ${ }^{2}$, Shakila Ahmad $^{3}$, Mohd Faizal Abdul Khir ${ }^{4}$, Abdul Hafiz Abdullah ${ }^{5}$, \\ Hani Suraya Aziz ${ }^{6}$, Shamsaadal Sholeh Saad ${ }^{7}$, Abdullah Sulaiman ${ }^{8}$ \\ ${ }^{I}$ Centre for General Studies and Co-curricular, Universiti Tun Hussein Onn Malaysia \\ ${ }^{2,5}$ Fakulti Tamadun Islam, Universiti Teknologi Malaysia \\ ${ }^{3,7,8}$ Centre for General Studies and Co-curricular, Universiti Tun Hussein Onn Malaysia \\ ${ }^{4}$ Faculty of Islamic Studies, Universiti Sultan Azlan Shah, Ipoh, Perak \\ ${ }^{6}$ Centre for Language Studies, Universiti Tun Hussein Onn Malaysia \\ *Corresponding author E-mail: harliana@uthm.edu.my
}

\begin{abstract}
Islam is the oldest established religion among Bulghar entity, the residents along the riverbanks of the Volga-Kama triangle. This valley was famous as the first Islamic country erected in the Eastern European region. The presence of Islam in the region has raised the name of the ruler of Volga Bulgaria and was reinforced by relationship with Baghdad. The Islamisation of the Bulghar society is relevant to the role played by Ahmad ibn Fadlan, the ambassador of the Abbasid government based in Baghdad. Therefore, this article aims to examine the role played by Ibn Fadlan in the Islamization of the Bulghar society. For this study, a qualitative method using historical descriptive approach was employed, which involved compilation and evaluation of the facts of the Risalah Ibn Fadlān. Data for this study were obtained through library research. The data analyses were conducted through texts and document analyses, as well as comparison method. This study finds that Ibn Fadlan plays an important role in the islamisation of the Bulghar society, not just as an ambassador of Abbasid government but as a teacher, preacher and counselor to the Bulghar king and the whole nation.
\end{abstract}

Keywords: Ibn Fadlan; Bulghar Society; Islamisation

\section{Introduction}

Islam is a major factor in the rise of the Bulghar society who inhabited the segments of the Volga-Kama Valley, around $900 \mathrm{AD}$. Islam has also been a major factor in the establishment of an Islamic territory named Volga Bulgaria in $922 \mathrm{AD}$, as a result of a relationship with Baghdad. The Islamisation of the Bulghar society and the establishment of an Islamic territory named Volga Bulgaria in $922 \mathrm{AD}$, was possible, thanks to the role played by $\mathrm{Ah}$ mad ibn Fadlan, the ambassador of the Abbasid government based in Baghdad. Therefore, this article aims to examine the role played by Ibn Fadlan in the Islamisation of Bulghar society. As for this study, the qualitative method using historical descriptive approach has been employed which involved compilation and evaluation of the facts of the Risalah Ibn Fadlān. Data for this study were obtained through library research. The data analyses were conducted through texts and document analyses, as well as comparison method.

\section{Ibn Fadlan's Biography}

The information on Ibn Fadlān's background is quite limited. However, based on compilation of the facts written by scholars in this research, his full name was Ahmad ibn Fadlān ibn al- ${ }^{\mathrm{c}}$ Abbās ibn Rashīd al-Khāsimi. Ibn Fadlan was a nickname given to him, where it was common in Arab societies to refer a scholar by his father's name; son of Fadlan. In the Encylopedia of Islam however, it stated that he is not from an Arab descent. A German scholar in the field of ancient geography, Paul Herrman, supported the view without an absolute correct confirmation, argued that Ibn Fadlān was a Greek resident in Baghdad who embraced Islam and gained credence and position during the ruling of Caliph al-Muqtadir.

His name became popular when his wrote Risalah, the official reports of the Baghdad delegation to the north that have considered as part of a valuable historical source on Islam in Russia during Abbasid reign in Baghdad. The wider version of his official note, Risalah about this delegation can be found in the work of Yāqūt ${ }^{\mathrm{c}}$ Abd Allah al-Hamawī.

Based on Ibn Fadlān's note, it can be concluded that he was not an expert in writing letters nor making notes. However, as a result of his deep observation and interest, he recorded each experience in his own way and made quite a complete record. Furthermore, he was entrusted with joining the delegation sent by Baghdad to Volga Bulgaria, thus his record was an official note of the delegation. This delegation was led by Sūsan al-Rasi, while Ibn Fadlan acted as a secretary to the delegation. The delegation was also accompanied by the Baris, a Bulghar as a travel guide to Volga Bulgaria. Initially, the delegation was also accompanied by the fuqaha', $\mathrm{mu}^{\mathrm{c}}$ allim, preachers, mullahs and merchant groups but only a few people continued to travel to Volga Bulgaria; Ibn Fadlan, al-Rassi, brother-in-law to al-Rassi, two Turkish slaves, a Turkish named Tekin, Baris and another travel guide named Qalwas.

His note was published in various prints, among others was Risalah Ibn Fadlān fi wasfi al-Rihlah ila Bilād al-Turk wa al-Khazr wa al-Rūs wa al-Saqālabah, published by Maktabah al-Thaqafah al-Diniyyah. In addition, Dar al-Kutub also published Ibn Fadlan's record of the same title. While the prints in the west used a slightly different title; Al-Risālah Ibn Fadlān: ma Shāhaduhu fi Bilād al-Turk wa al-Khazr wa al-Rūs wa al-Saqālabah wa alBashghird wa Ghairihim. 


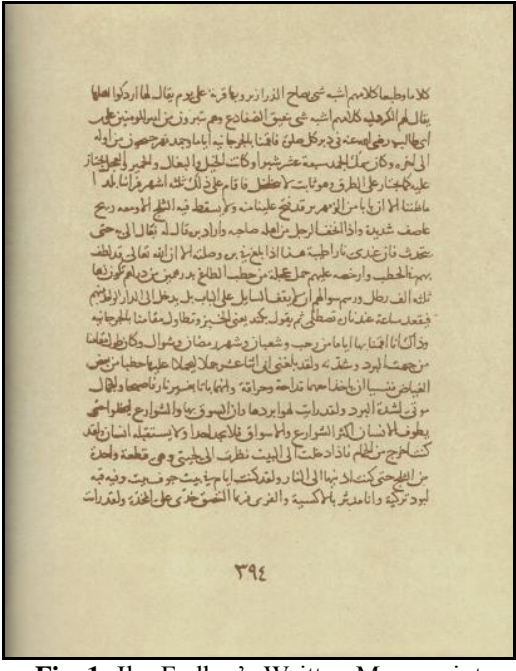

Fig. 1: Ibn Fadlan's Written Manuscript

\section{Ibn Fadlan's Role in The Islamisation of Bulghar Society}

The role of Ibn Fadlān as the delegation secretary has been a major source for subsequent historical researchers, as he was responsible for recording every step of the journey and the events that occurred to be reported to the Caliph in Baghdad. As a result of his deep observation and interest, he has recorded every experience in his own way and made it a quite complete record. He also notes how he played the role of a teacher, preacher and counselor to the Bulghar community and became a reference to the Bulghar leader to rule the Volga Bulgaria as an Islamic territory.

The journey began on Thursday, 11 Safar 309/4 June 921 AD, the Baghdad delegation to Volga Bulgaria under the direction of the Caliph al-Muqtadir left the city of Baghdad to the town of Khwarizm before continuing their journey to the north.

The failure of delegates to secure financial resources did not affect their travel, which was only accompanied by a few members, namely Ahmad ibn Fadlān, Sūsan al-Rasi, his brother-in-law, Baris, Tekin and a servant, but the journey to Volga Bulgaria continues to achieve the end of the delegation's goal of establishing an official relationship of Baghdad-Volga Bulgaria (1).

Apart from the formal relationship between Volga Bulgaria and Baghdad, one of the goals of the Baghdad delegation (especially Ibn Fadlān) in Volga Bulgaria is to strengthen Islam, introducing Islamic laws while helping to build a new mosque and its pulpit as well as trying to convey Islamic treaties throughout Volga Bulgaria.

\section{Ahmad bin Fadlan has said;}

Upon the letter of Almash bn Yaltuwar, the King Saqalibah to Amir al-Mukminin al-Muqtadir, (in which the letter) (Almash) had requested a delegation (sent) to the king from among the people who taught the religion, explains to him .(2)

... the Shariah of Islam, built the mosque for him and established the minbar for the purpose of conveying his mission to the king in his country and all its subordinates. He also applied for the construction of the fortress that fascinated him from the rulers who opposed him. So the request was granted (by al-Muqtadir) (2)

All that was mentioned were mission, trust and responsibility that must be fulfilled and perfected, even when the delegates faced problems and obstacles along the way. The Baghdad delegation, after discussing with the Volga Bulgaria, has set the date of the handing over ceremony of the Caliph's recognition certificate at 16 Muharram 310/15 May 922, four days after arriving. The recognition from Baghdad on that day was presented by Ibn Fadlan to the Bulgarian Volga government as representative of the Abbasid caliph.

Ibn Fadlan said;
I have handed over all the gifts to him, his queen and his children, his relatives and his military chiefs and the medicines requested... (2)

The award was presented in the form of the official dress of Islamic state leaders; a black cloak and white turban as a sign that $\mathrm{Al}-$ mas, the Volga Bulgaria king has been recognised as an Islamic ruler under the auspices of Baghdad.

The role of Ibn Fadlan in the process of islamisation of the Bulghar society can also be seen in his note;

I was delegated to read the letter to him, handed him a gift that he was awarded to him, supervising the fuqaha' and teachers, storing the property he provided for him to build all that had been and the payment to the fuqaha and the teacher... $(2,3)$

However, the delegates failed to bring along with them the scholars expected by the Volga Bulgaria government due to the failure to seek financial assistance from the Central Asian states. The hired scholar, as termed by Bukharaev, refused to continue traveling because they were afraid that they did not get the expected reward (2001). Hence, the demand from Volga Bulgaria regarding the need for groups of religious teachers to teach Muslim Bulghars has been taken over by Ibn Fadlan and other delegates.

Ibn Fadlan also taught the preparation of prayer in reading sermons. The King of Bulghar changed his name to $\mathrm{Ja}^{\mathrm{c}}$ far bin Abdullah, to be mentioned in the reading of the sermon because he is a Muslim ruler (3). Ibn Fadlan also corrected Islamic practices of the Bulghar Muslim society, for example the reading of iqamah, which was recited twice by them initially.

$\mathrm{He}$ also adviced the king to apply Islamic practices on distribution of inheritance. In the Bulghar society, when someone dies, his brother will be the heir of his estate and not his son. This practice is clearly in contrast to Islamic practice which places the main heir to the estate of the deceased man to his son and wife.

\section{Ibn Fadlan said ;}

I inform the King that this is unlawful, and clarifies [the principle of inheritance [according to Muslim law] until he understands it.

In addition, among the people of Volga Bulgaria, there is an ethnic known as Barandjar. This ethnic group of five thousand, including men and women, was the earliest group that embraced Islam. They have built a wooden mosque where they perform prayers. However, they could not read the al-Quran. Ibn Fadlan, along with other delegates, taught a group of them how to perform prayers and the discipline of prayers.

Islamic da'wah shone in Volga Bulgaria through the role played by Ibn Fadlan and his friends. There is an increase in those who want to embrace Islam based on his notes. This was clearly seen from the events when Ibn Fadlan taught syahadah to a man and named him Muhammad.

\section{Ibn Fadlan said;}

A man had embraced Islam in my hand named Talut, and I named him 'AbdAllah. He said: "I want you to call me by your name, 'Muhammad'." And I did it: His wife, his mother and his children also accepted Islam, and all of them were called Muhammad. I taught him 'Alhamdulillah' and I taught him syahadah. Say: He is God, the One and Only (3).

Although Ibn Fadlan and Baghdad's delegates faced challenges in carrying out their responsibilities as teachers, preachers and counselors to the Bulghar king and the whole country, the challenge did not prevent the islamisation process from happening. The Volga Bulgaria ruler and its people were becoming more aware of Islam and embracing the spirit that was brought by Islam. This is evident in the implementation of Islamic laws as desired by Volga Bulgaria government and the increase of religious awareness among the Bulghar society.

\section{Conclusion}

The role played by the members of the delegation, approximately four people, has been helping leader of Volga Bulgaria to govern the society according to the foundation of Islam. Ibn Fadlān's notes on his role and other members of the Baghdad delegation in 
teaching the Volga Bulgaria people on the question of Islam clearly proved that the social goals expected by the Volga Bulgaria government as a Muslim territory in Russia have been achieved. The assistance provided by the delegation of Baghdad, Ibn Fadlan particularly, were meaningful in providing the awareness to the people of Volga Bulgaria to adopt the Islamic way of life and leave the pagan way of life (jahiliyyah) that has been practiced before.

\section{Acknowledgement}

This research is funded by the Ministry of Higher Education through, Research Acculturation Collaborative Effort Grant (RACE), Vot 1516 Universiti Tun Hussein Onn Malaysia. Special thanks you to RACE Grant Secretariat, Ministry of Higher Education Malaysia, Research Management Centre UTHM, Centre for General Studies and Co-curricular (PPUK), Universiti Tun Hussein Onn Malaysia, Faculty of Islamic Civilization (FTI) and RMC Universiti Teknologi Malaysia.

\section{References}

[1] Halim H, Yusoff K, Ghazalli AJ. Relations between volga bulgaria and baghdad. International Business Management. 2013;7(1):21-30

[2] Frye RN. Ibn Fadlan's Journey to Russia. A tenth century traveler from Baghdad to the Volga River Princeton. 2005.

[3] Fadlān AI. Ibn Fadlan and the land of Darkness: Arab travellers in the Far North: Penguin UK; 2012. 